\title{
Influenza vaccination rate
} among emergency department personnel:
a survey of four teaching hospitals

\author{
Inderpal Saluja, MD; ${ }^{*}$ Karl D. Theakston, MSc, MD; ${ }^{\dagger}$ Janusz Kaczorowski, $\mathrm{PhD}^{\dagger}$
}

\begin{abstract}
Objectives: To determine influenza vaccination rates and attitudes toward vaccination among emergency department health care workers at 4 Ontario teaching hospitals.

Methods: During the influenza season of 1999-2000 a confidential 28-item survey was distributed to emergency physicians and residents, nurses, respiratory therapists, and other allied health care workers at the emergency departments of 4 London, Ontario teaching hospitals.

Results: Of 426 surveys distributed, 343 were returned, for an overall response rate of $80.5 \%$. The mean age of respondents was 38.5 years (standard deviation $=8.3$ ), $74.3 \%$ were female, and $86.6 \%$ were non-smokers. The overall vaccination rate was $37.0 \%$ (95\% confidence interval, $31.9 \%-42.4 \%$ ). Vaccination rates were $45.9 \%$ for respiratory therapists, $35.3 \%$ for emergency physicians and residents, $34.5 \%$ for nurses and $27.1 \%$ for other allied health care workers $(p=$ 0.083 ). Multivariate logistic regression analysis revealed that age $\geq 41$ and a chronic medical condition were positively associated with influenza vaccination $(p<0.05)$. Close to one-third of respondents $(28.3 \%)$ believed that adverse affects were common, $51.6 \%$ believed vaccination was effective, $52 \%$ would support a program to improve vaccination rates among emergency department staff, and $24.4 \%$ would support mandatory vaccination for this population. Only $26.8 \%$ believed that patients were at increased risk of contracting influenza from emergency department staff, but $58.3 \%$ perceived that emergency department staff were at increased risk of contracting influenza through exposure to patients.

Conclusions: In this study, only $37 \%$ of emergency department health care workers were immunized against influenza, with chronic illness and older age being the only 2 significant correlates. Strategies to improve emergency department health care worker attitudes toward influenza vaccination for themselves and to increase vaccination rates for this population should be developed.

Key words: influenza; vaccination; health care workers; personnel, emergency department; prevention, influenza; pandemic; epidemic; survey; cross-sectional studies; emergency services, hospital

RÉSUMÉ

Objectifs : Déterminer les taux de vaccination contre la grippe et les attitudes face à la vaccination parmi les travailleurs de la santé dans les départements d'urgence dans quatre hôpitaux universitaires en Ontario.
\end{abstract}

*Department of Emergency Medicine, Grand River Hospital, Kitchener, Ont.

†Assistant Professor, Division of Emergency Medicine, University of Western Ontario, London, Ont., and Site Chief, University Campus, Department of Emergency Medicine, London Health Sciences Centre, London, Ont.

¥Associate Professor and Research Director, Department of Family Medicine, Department of Clinical Epidemiology and Biostatistics, McMaster University, Hamilton, Ont.

Received: Mar. 5, 2004; final submission: Sept. 28, 2004; accepted: Oct. 5, 2004

This article has been peer reviewed.

Can J Emerg Med 2005;7(1):17-21 
Méthodes : Au cours de la saison de la grippe de 1999-2000, un sondage confidentiel en 28 points fut distribué aux médecins et résidents, aux infirmières, aux inhalothérapeutes et à d'autres professionnels paramédicaux dans les départements d'urgence de quatre hôpitaux universitaires à London en Ontario.

Résultats : Parmi 426 sondages distribués, 343 furent retournés, pour un taux de réponse de $80,5 \%$. L'âge moyen des répondants était de 38,5 ans (écart-type $=8,3$ ), $74,3 \%$ étaient des femmes et $86,6 \%$ étaient non fumeurs. Le taux de vaccination global était de $37,0 \%$ (intervalle de confiance $95 \%, 31,9 \%-42,4 \%$ ). Les taux de vaccination étaient de $45,9 \%$ pour les inhalothérapeutes, de 35,3\% pour les médecins d'urgence et les résidents, de $34,5 \%$ pour les infirmières et de $27,1 \%$ pour les autres professionnels paramédicaux $(p=0,083)$. L'analyse de régression logistique multivariée révéla qu'un âge $\geq 41$ ans et une atteinte médicale chronique étaient associés positivement à la vaccination contre la grippe $(p<0,05)$. Près du tiers des répondants $(28,3 \%)$ croyaient que les effets indésirables étaient courants, $51,6 \%$ croyaient que la vaccination était efficace, $52 \%$ appuieraient un programme pour améliorer les taux de vaccination au sein du personnel du département d'urgence et $\mathbf{2 4 , 4} \%$ appuieraient la vaccination obligatoire pour cette population. Seulement $26,8 \%$ des répondants croyaient que les patients couraient un risque accru d'attraper la grippe du personnel du département d'urgence, mais 58,3\% percevaient que le personnel du département d'urgence courait un risque accru d'attraper la grippe par le biais des contacts avec les patients.

Conclusions : Dans la présente étude, seulement $37 \%$ des travailleurs de la santé au département d'urgence ont été vaccinée contre la grippe, les maladies chroniques et l'âge plus avancé étant les deux seuls corrélats significatifs. Les stratégies pour améliorer les attitudes des travailleurs de la santé dans les départements d'urgence face à la vaccination contre la grippe pour eux-mêmes et pour augmenter les taux de vaccination pour cette population devraient être mises sur pied.

\section{Introduction}

Influenza has caused the death of millions of people and played an important role in the history of medicine and disease. The 1918 influenza pandemic infected one-fifth of the world's population, including $25 \%$ of the US population, and it killed between 20 and 100 million people worldwide. ${ }^{1}$ Most of its victims were young, ${ }^{2}$ and medical facilities were overwhelmed.

Vaccination is the most effective strategy we have against influenza. Two recent studies ${ }^{3,4}$ demonstrated that vaccination of health care workers reduced mortality in the elderly patients they were caring for. Similarly, a recent meta-analysis and a randomized double-blind placebo-controlled trial concluded that health care worker immunization reduces pneumonia rates, hospitalization and mortality among elderly patients. ${ }^{5,6}$ Influenza vaccine also prevents infection in healthy adults; $;^{7-9}$ therefore, province-wide vaccination programs operating currently have the potential to save lives and prevent outbreaks, but these programs have not been adequately studied.

Influenza vaccination of emergency department (ED) health care workers is important because it reduces disease transmission to patients and prevents secondary outbreaks, thereby decreasing morbidity and mortality. Low immunization rates among ED health care workers may con- tribute to the occurrence of influenza outbreaks. The objective of this study was to estimate the frequency of vaccination among ED health care workers and to identify factors associated with the decision to receive a vaccination.

\section{Methods}

\section{Setting}

This cross-sectional survey was conducted in the emergency departments of 4 London, Ontario teaching hospitals.

\section{Survey development}

The survey was designed by 2 of the authors (I.S. and K.D.T.) and was pre-tested on office staff, who provided feedback regarding potential bias, clarity and appropriateness of the questions. The first section solicited demographic information, including occupation, gender, age, marital status, and the presence of children in the house. The second section focused on the individual's health, documenting risk factors and comorbid conditions such as smoking, asthma, diabetes, cancer, and respiratory, blood, heart, liver or bowel disease. Respondents who reported receiving a flu shot were asked why they decided to be vaccinated, and all respondents were asked to describe their attitude toward influenza vaccination, including feelings about future vaccination programs, perceived effectiveness 
of the vaccine, and perceived risks to patients and health care workers who are exposed to unvaccinated people.

\section{Sampling}

A questionnaire and explanatory letter were distributed to all ED staff who are exposed to patients during their work hours, including medical personnel (physicians, residents, respiratory therapists and nurses) and allied health care workers (clerical staff, personal and technical support attendants, orderlies, clerks and office staff). The 28-item questionnaires were placed into the mailboxes of the staff, and a survey return box was located nearby for completed questionnaires. All questionnaires were numbered, and these numbers corresponded to names on staff lists from each participating emergency department. To maintain respondent confidentiality, an independent assistant unrelated to the study collected the surveys and arranged for remailing to non-responders.

Surveys were distributed between March and April 2000, with an initial response deadline of June 2000. After the initial deadline, staff who did not return a survey were contacted by internal mail with another copy of the survey, again through the use of hospital mailboxes. A follow-up letter reiterated the study purpose and urged the respondent to complete and return his or her survey.

\section{Data analysis}

Univariate logistic regression analysis was performed to determine the associations between respondent characteristics and vaccination. Predictor variables that were significantly associated with vaccination $(p<0.10)$ were retained in multivariate models using forward and backward stepwise multivariable logistic regression and the likelihood ratio method. The probability of a type I error in the final models was chosen to be 0.05 (two-tailed). Goodness of fit for the logistic-regression models was examined by use of the Hosmer-Lemeshow goodness-of-fit test. Analyses were performed using SPSS (version 10.0, SPSS Inc., Chicago, Ill.) and this study was conducted in accordance with the survey guidelines of the local institutional research ethics review board.

\section{Results}

Of 426 questionnaires distributed, 343 (80.5\%) were returned. Table 1 summarizes characteristics and influenza vaccination rates for the survey respondents. The mean age was 38.5 years (standard deviation $=8.3$ ), $74.3 \%$ of respondents were female and $86.6 \%$ were non-smokers. Overall, 34 were physicians or residents, 139 were nurses,
111 were respiratory therapists, and 59 were allied health care workers (i.e., non-clinical staff, including clerical staff, personal and technical support attendants, orderlies, clerks and office staff).

Overall, $37.0 \%$ (95\% confidence interval [CI], $31.9 \%-42.4 \%$ ) reported that they had been vaccinated against influenza. Vaccination rates reported by respiratory therapists, emergency physicians and residents, nurses and other allied health care workers were $45.9 \%, 35.3 \%$, $34.5 \%$ and $27.1 \%$ respectively ( $p=0.083$ ) (Fig. 1). Multivariate logistic regression analysis revealed that age $\geq 41$ (odds ration $[\mathrm{OR}]=1.9 ; 95 \% \mathrm{CI}, 1.1-3.4 ; p=0.04$ ) and a chronic medical condition $(\mathrm{OR}=1.6 ; 95 \% \mathrm{CI}, 1.0-2.5 ; p=$ 0.02 ) were positively associated with influenza vaccination. The Hosmer-Lemeshow goodness-of-fit statistic showed an adequate fit for the model (chi-squared $=0.37$,

\begin{tabular}{|c|c|c|c|}
\hline Variable (and no.) & $\begin{array}{c}\text { No. } \\
\text { (and \%) } \\
\text { vaccinated }\end{array}$ & $\begin{array}{l}\text { Crude OR } \\
(95 \% \mathrm{Cl})\end{array}$ & $p$ value \\
\hline \multicolumn{4}{|l|}{ Occupation } \\
\hline Nurses (139) & $48(34.5)$ & $1.0+$ & - \\
\hline $\begin{array}{l}\text { Respiratory } \\
\text { therapists (111) }\end{array}$ & $51(45.9)$ & $1.6(0.9-2.7)$ & 0.07 \\
\hline $\begin{array}{l}\text { Allied health } \\
\text { workers (59) }\end{array}$ & $16(27.1)$ & $0.7(0.4-1.4)$ & 0.31 \\
\hline $\begin{array}{l}\text { Physicians / residents } \\
\text { (34) }\end{array}$ & $12(35.3)$ & $1.0(0.5-2.3)$ & 0.93 \\
\hline \multicolumn{4}{|l|}{ Gender } \\
\hline Male (87) & $36(41.4)$ & $1.0 \dagger$ & - \\
\hline Female (255) & $90(35.3)$ & $0.8(0.5-1.3)$ & 0.31 \\
\hline \multicolumn{4}{|l|}{ Marital status } \\
\hline Single (96) & $32(33.3)$ & $1.0+$ & - \\
\hline $\begin{array}{l}\text { Married / } \\
\text { common-law (241) }\end{array}$ & $241(38.2)$ & $1.2(0.8-2.0)$ & 0.41 \\
\hline \multicolumn{4}{|l|}{ Children at home } \\
\hline No (152) & $55(36.2)$ & $1.0 \dagger$ & - \\
\hline Yes (187) & $71(38.0)$ & $1.1(0.7-1.7)$ & 0.74 \\
\hline \multicolumn{4}{|l|}{ Smoking status } \\
\hline Non-smoker (297) & $109(36.7)$ & $1.0 \dagger$ & - \\
\hline Smoker (44) & $16(36.4)$ & $1.0(0.5-1.9)$ & 0.97 \\
\hline \multicolumn{4}{|l|}{ Chronic diseasesł } \\
\hline No (279) & $94(33.7)$ & $1.0+$ & - \\
\hline Yes (63) & $32(50.8)$ & $2.0(1.2-3.5)$ & 0.01 \\
\hline \multicolumn{4}{|l|}{$\begin{array}{l}\text { Age }(\text { mean }=38.5 \\
\quad S D=8.3)\end{array}$} \\
\hline$\leq 40$ years old (191) & $63(33.0)$ & $1.0 \dagger$ & - \\
\hline$\geq 41$ years old $(140)$ & $62(44.3)$ & $1.6(1.0-2.5)$ & 0.04 \\
\hline
\end{tabular}

$\mathrm{OR}=$ odds ratio; $\mathrm{Cl}=$ confidence interval; $\mathrm{SD}=$ standard deviation

* Numbers may not add up to totals due to missing data.

tReference category

‡Diabetes, asthma, respiratory disease, blood, heart, liver or bowel disease, cancer 
degree of freedom $=8, p=0.831$ ). Of those who received influenza vaccine in the 1999-2000 season, 65.9\% had also been vaccinated in previous years. Amongst those who did not receive vaccine in 1999-2000, 16.7\% had been vaccinated in the past. Length of employment, gender, smoking history and marital status were not significantly correlated with the likelihood of being vaccinated.

Of those vaccinated, $89.5 \%$ were immunized at the hospital and $7.3 \%$ were immunized by their family doctor. Although $28.3 \%$ of respondents believe that vaccine adverse effects are common, most $(76.8 \%)$ of those vaccinated reported no adverse effects. Half of respondents believe that influenza immunization is effective, $17.9 \%$ thought it is ineffective and $31.3 \%$ were unsure. Overall $28.3 \%$ felt that they were not well informed about the vaccine or its effectiveness. Most health care workers $(58.3 \%)$ believe they are at risk of contracting influenza from patients, whereas only $26.8 \%$ felt that patients are at risk of contracting influenza from health care workers. When asked about the future, $47.3 \%$ of respondents planned to get the flu shot the following year. Approximately half of the respondents (51.6\%) would support a vaccination program at work to help improve rates, but only $24.4 \%$ supported a mandatory program.

\section{Discussion}

Although vaccination of health care workers has been shown to improve patient outcomes, only $37 \%$ of ED health care workers in this study had been vaccinated against influenza. The study data show that older health care workers and those with chronic medical conditions were more likely to accept vaccination, and that other variables such as smoking, marital status, length of employment and having children in the house were not related to

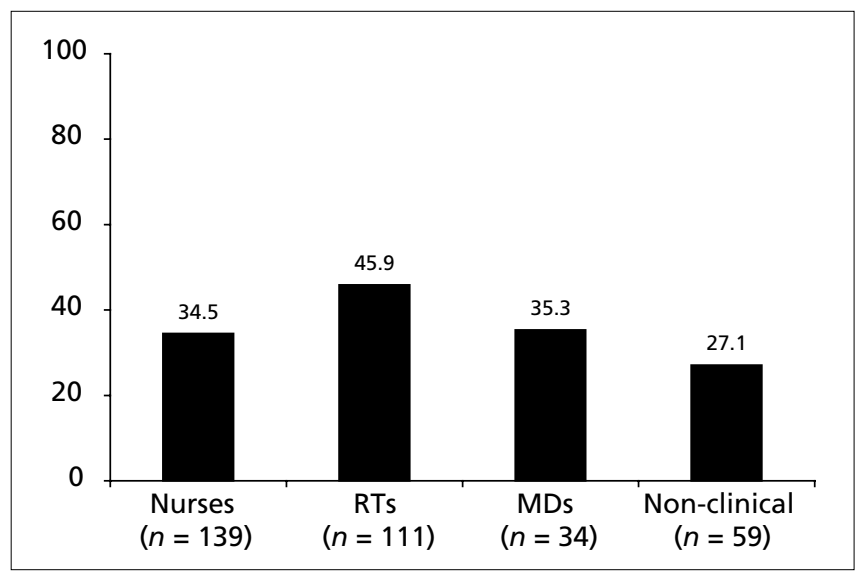

Fig. 1. Influenza vaccination rates by occupation of respondent vaccination. Health care workers believed that the risk of disease transmission from patients to health care workers is greater than the risk of transmission from health care workers to patients.

A recent study found that previous vaccination, a belief that prevention is important, and belief that vaccination is effective are associated with higher health care worker vaccination rates. ${ }^{10}$ Other factors associated with vaccination are older age, female gender, marriage, longer employment, higher income, minimal absenteeism (nurse clinicians), employment duration (professional support staff) and older age (non-professional staff). ${ }^{11}$ Thomas and colleagues showed that educational interventions are helpful and that health care worker vaccination rates increased from $8 \%$ to $46 \%$ when an educational intervention was followed by a vaccination fair. ${ }^{12}$

A multicentre study of health care workers showed that between $28 \%-59 \%$ of influenza cases are subclinical, that $23.2 \%$ of health care workers had a rise in influenza titres, but that only $8 \%$ took sick leave. ${ }^{13}$ This suggests that health care workers tend to work when they are sick, and that many may not know they are harbouring virus. This increases the likelihood of spread to susceptible individuals, especially those who have not been vaccinated.

Although health care worker vaccination reduces patient mortality in long-term care facilities, the same has not been clearly shown in the ED setting, and these data would help clarify the cost-effectiveness of future vaccination programs directed specifically at emergency department personnel.

\section{Limitations}

An important limitation of this study is the fact that all data were self-reported. The accuracy of the responses therefore depended on each respondent's recollection of being vaccinated and the willingness to admit they had not been vaccinated. The number of physicians surveyed was small, limiting the precision of estimates in this group, and external validity is uncertain, although these data reflect all hospitals in the city of London, Ontario. Finally, since the data is 4 years old, it is possible that health care workers' attitudes may have changed as the result of recent infectious disease outbreaks.

\section{Conclusions}

Future research should assess the effectiveness of educational and other interventions on improving health care worker vaccination rates, and might focus on younger health care workers with no chronic medical conditions, 
who may perceive themselves as being less susceptible to influenza.

In this study, only $37 \%$ of ED health care workers were immunized, with chronic illness and older age being the only two significant correlates. Strategies to increase health care worker vaccination rates should be developed.

Competing interests: None declared.

\section{References}

1. Kolata G. Flu: the story of the great influenza pandemic of 1918 and the search for the virus that caused it. New York: Farrar Strauss and Giroux; 1999.

2. Osborn JE. History, science, and politics: influenza in America, 1918-1976. New York: Prodist; 1977. p. 135

3. Carman WF, Elder AG, Wallace LA, McAulay K, Walker A, Murray GD, et al. Effects of influenza vaccination of health-care workers on mortality of elderly people in long-term care: a randomised controlled trial. Lancet 2000;355:93-7.

4. Potter J, Stott DJ, Roberts MA, Elder AG, O'Donnell B, Knight $\mathrm{PV}$, et al. Influenza vaccination of health care workers in longterm-care hospitals reduces the mortality of elderly patients. J Infect Dis 1997;175:1-6.

5. Gross PA, Hermogenes AW, Sacks HS, Lau J, Levandowski RA. The efficacy of influenza vaccine in elderly persons: a meta-analysis and review of the literature. Ann Intern Med 1995;123:518-27.

6. Govaert TM, Thijs CT, Masurel N, Sprenger MJ, Dinant GJ, Knottnerus JA. The efficacy of influenza vaccination in elderly individuals. A randomized double-blind placebo-controlled trial. JAMA 1994;272;1661-5.

7. Bridges CB, Thompson WW, Meltzer MI, Reeve GR, Talamonti WJ, Cox NJ, et al. Effectiveness and cost-benefit of influenza vaccination of healthy working adults: a randomized controlled trial. JAMA 2000;284:1655-63.

8. Nichol KL, Lind A, Margolis KL, Murdoch M, McFadden R, Hauge $M$, et al. The effectiveness of vaccination against influenza in healthy, working adults. N Engl J Med 1995;333;889-93.

9. Wilde JA, McMillan JA, Serwint J, Butta J, O'Riordan MA, Steinhoff MC. Effectiveness of influenza vaccine in health care professionals. JAMA 1999;281(10):908-13.

10. Beguin C, Boland B, and Ninane J. Health care workers: vectors of influenza virus? Low vaccination rate among hospital health care workers. Am J Med Qual 1998;13:223-7.

11. Doebbeling BN, Edmond MB, Davis CS, Woodin JR, Zeitler RR. Influenza vaccination of health care workers: evaluation of factors that are important in acceptance. Prev Med 1997;26:68-77.

13. Elder AG, O'Donnell B, McCruden EAB, Symington IS, Carman WF. Incidence and recall of influenza in a cohort of Glasgow healthcare workers during the 1993-4 epidemic: results of serum testing and questionnaire. BMJ 1996;313:1241-2.

12. Thomas DR, Winsted B, Koontz C. Improving neglected influenza vaccination among healthcare workers in long-term care. J Am Geriatr Soc 1993;41:928-30.

Correspondence to: Dr. Inderpal Saluja, Department of Emergency Medicine, Grand River Hospital, 835 King St. West, Kitchener ON N2G 1G3; salujai@yahoo.ca 